\title{
Genetics of fat storage in flies and worms: what went wrong?
}

\section{Bader Al-Anzi and Kai Zinn*}

Division of Biology, California Institute of Technology, Pasadena, CA, USA

*Correspondence: zinnk@caltech.edu

Body weight and fat storage are strongly influenced by an individual's genetic makeup. In humans, genetic polymorphisms have been identified that have effects on body mass index (BMI) and fat content (Meyre et al., 2009; Speliotes et al., 2010; Choquet and Meyre, 2011a), and studies of monogenic rodent models of obesity have defined a variety of genes and signaling pathways that control fat storage and metabolism (Barsh and Schwartz, 2002). However, many other genes that regulate these processes undoubtedly remain to be discovered. Although forward genetic screens in the mouse have the potential to identify new obesity genes, such screens are expensive and lengthy endeavors.

The fruit fly Drosophila melanogaster and the nematode (roundworm) Caenorhabditis elegans have provided powerful genetic models for establishing the genetic foundations of many biological phenomena. Forward genetic screens in flies and worms can be performed quickly and inexpensively, so the use of these model systems for obesity research has the potential to accelerate the rate of gene discovery. At least two fat-regulating genes first identified in Drosophila were also shown to affect fat content in mice (Suh et al., 2007; Pospisilik et al., 2010). These genes have not yet been examined in the context of human obesity.

In Drosophila, the most frequently used method for measurement of fat is a coupled colorimetric triglyceride assay kit (CCA). In C. elegans, the typical methodology for high-throughput screening involves mixing Nile Red, a vital dye that stains lipid droplets, with the E. coli bacteria on which the worms feed. Large RNAi screens have been performed using these assays. In total, such screens have identified about 500 Drosophila and 400 C. elegans genes for which RNAi perturbation affects fat storage (Ashrafi et al., 2003; O'Rourke et al., 2009; Pospisilik et al., 2010). Among the conserved molecules that would be expected to be involved in fat storage based on mammalian studies, the Drosophila screen identified members of the TOR pathway and mediators of glucose and lipid mobilization, and the first $C$. elegans screen identified a serotonin receptor and the Tubby homolog. However, the vast majority of the genes found in these screens had not been previously implicated in control of fat storage and metabolism, and therefore represent new targets for future analysis.

Unfortunately, recently published results show that the high-throughput assays used in these screens do not provide accurate assessments of stored fat content. Thus, it is unclear whether the new genes identified in the screens are genuine regulators of fat deposition and metabolism.

The CCA relies on hydrolysis of triglycerides by a lipoprotein lipase to generate glycerol, which is then phosphorylated and oxidized to produce hydrogen peroxide. The amount of hydrogen peroxide generated from glycerol is read out using a peroxidase reaction to generate products called quinoneimines that absorb light in the visible range. Although CCA provides accurate readings when used to measure serum triglycerides, which are components of soluble lipoprotein complexes, it is unsuitable for measuring stored fat in tissue samples. First, it fails to give accurate readings when tested on insoluble triglyceride mixtures that resemble stored fat within cells, or on purified fly fat (Van Veldhoven et al., 1997; Al-Anzi and Zinn, 2010). This is because the lipases used in the kits cannot efficiently cleave the fatty acid-glycerol bonds in insoluble lipid mixtures. (Reference Van Veldhoven et al., 1997 shows that resuspension of stored fat samples from mammalian cells with a specific detergent can improve cleavage and allow more accurate assessment of insoluble fat; this method has not been applied to Drosophila.) Second, CCA actually measures the phosphorylatable glycerol backbones present in the samples being evaluated. Cleavage of non-fat glycerides such as mono- and di-glycerides by the assay kit lipases also generates glycerol. Thus, when CCA is used to evaluate tissue extracts, the observed signal actually represents the amount of free glycerols in the tissue together with all types of glycerides (Van Veldhoven et al., 1997; Al-Anzi and Zinn, 2010). Third, when CCA is used on whole crushed Drosophila samples, the signal-tonoise ratio is influenced by compound eye pigments, whose absorption spectra overlap with those of the peroxidase reaction products that are measured as the final output of the assay (Al-Anzi and Zinn, 2010).

Very recently, a response to $\mathrm{Al}$-Anzi and Zinn (2010) was published that defended the use of CCA for evaluation of fat content in Drosophila (Hildebrandt et al., 2011). These authors showed that strains that are higher in fat content can generate larger CCA signals, and noted that CCA readings can be corrected for eye pigment absorption and free glycerol differences by measuring blank reactions in which lipase and/or peroxidase substrates are omitted (this was not done in the published highthroughput screen (Pospisilik et al., 2010).) However, even when these corrections are performed, CCA still cannot accurately measure insoluble fat and cannot distinguish between triglycerides, diglycerides, and monoglycerides (Van Veldhoven et al., 1997; Al-Anzi and Zinn, 2010). In any large-scale CCA screen, there will be both false positives (strains that give different CCA readings from controls but do not actually differ in triglyceride content) and false negatives (strains that do not differ from controls when assessed by CCA, but which actually are different in triglyceride content). False positives can be eliminated using other assays for secondary screening, but false negatives cannot be detected, and these genes will simply be missed.

For the vital Nile Red assay, four papers showed that when Nile Red is fed to live C. elegans, it stains lysosome-related organelles (LROs), not lipid droplets (Brooks et al., 2009; O'Rourke et al., 2009; Yen et al., 2010; Zhang et al., 2010). (However, a recent chemical screening paper argued that live Nile Red staining does report on 
fat content; Lemieux et al., 2011). The lack of lipid droplet staining by fed Nile Red may be due to preferential uptake into endolysosomal pathway vesicles, which are a degradative compartment. Intact Nile Red may be unable to move from these vesicles into lipid droplets. This hypothesis is supported by the observation that ingested Nile Red does label lipid droplets in mutants that lack a functional peroxisomal beta-oxidation pathway (Zhang et al., 2010). Lipid droplets can also be stained by Nile Red in fixed worms. In these preparations, membranes are damaged, and Nile Red can incorporate into lipid droplets by direct permeation (Brooks et al., 2009; O'Rourke et al., 2009; Yen et al., 2010; Zhang et al., 2010).

Given the problems with the assays used for the published screens, what methods should be employed for future fat storage screens in the Drosophila and C. elegans systems? In Drosophila, thin-layer chromatography (TLC) provides an inexpensive and straightforward method for direct measurement of triglycerides in extracts of whole flies, and it is not confounded by eye pigment or by other glycerols and glycerides (Al-Anzi et al., 2009; Al-Anzi and Zinn, 2010). However, TLC results obtained from tissue extracts must be confirmed by histological analysis of tissue sections to visualize lipid droplets in adipose tissue. The histological conformation of an obese or thin phenotype is essential since changes in overall triglyceride levels might due to circulating triglycerides and not to stored fats. In $C$. elegans, lipid droplets can be visualized by using Oil Red-O, Nile Red, or Sudan Black to stain fixed worms (Brooks et al., 2009; O’Rourke et al., 2009; Yen et al., 2010; Zhang et al., 2010). A technique called Coherent Raman Anti-Stokes (CARS) microscopy can accurately assess fat stores in living worms, but this requires sophisticated technology and expertise and may not be readily applicable to future large-scale screens (Yen et al., 2010).

An additional issue that could potentially affect the results of screens conducted by feeding worms with dsRNA-producing bacteria is that fat storage and feeding behavior are linked processes. For example, mice and humans lacking leptin signaling are obese, but they also eat more than normal individuals (Choquet and Meyre, 2011b). It is possible that if RNAi perturbation affects the level of fat storage in worms, it will have a feedback effect on food intake, and thus alter the amount of the dsRNA-containing bacteria consumed and the resulting efficacy of RNAi silencing. This may affect the accuracy of comparisons of fat storage levels between worms fed with different dsRNAs, adding an undesirable layer of complexity to the interpretation of the data. It is thus important to use classical mutant analysis to validate any conclusions reached from RNAi experiments. It will also be important to move beyond the description of genes that alter fat storage to an examination of the behavioral and metabolic changes produced by genetic manipulations. Behavioral and metabolic assays do exist for Drosophila and other flies, but there is room for improvement. For C. elegans, it would be beneficial for future research to develop such assays. In particular, it would be valuable to have a direct method to measure how much a worm eats instead of indirectly inferring consumption from pharyngeal pumping rates.

\section{REFERENCES}

Al-Anzi, B., Sapin, V., Waters, C., Zinn, K., Wyman, R. J., and Benzer, S. (2009). Obesity-blocking neurons in Drosophila. Neuron 63, 329-341.

Al-Anzi, B., and Zinn, K. (2010). Colorimetric measurement of triglycerides cannot provide an accurate measure of stored fat content in Drosophila. PLoS ONE 5, e12353. doi: 10.1371/journal.pone.0012353

Ashrafi, K., Chang, F.Y., Watts, J. L., Fraser, A. G., Kamath, R. S., Ahringer, J., and Ruvkun, G. (2003). Genomewide RNAi analysis of Caenorhabditis elegans fat regulatory genes. Nature 421, 268-272.

Barsh, G. S., and Schwartz, M. W. (2002). Genetic approaches to studying energy balance: perception and integration. Nat. Rev. Genet. 3, 589-600.

Brooks, K. K., Liang, B., and Watts, J. L. (2009). The influence of bacterial diet on fat storage in C. elegans. PloS ONE 4, e7545. doi: 10.1371/journal.pone.0007545

Choquet, H., and Meyre, D. (2011a). Molecular basis of obesity: current status and future prospects. Curr. Genomics 12, 154-168.

Choquet, H., and Meyre, D. (2011b). Genetics of obesity: what have we learned? Curr. Genomics 12, 169-179.

Hildebrandt, A., Bickmeyer, I., and Kuhnlein, R. P. (2011). Reliable Drosophila body fat quantification by a coupled colorimetric assay. PLOS ONE 6, e23796. doi: 10.1371/journal.pone.0023796

Lemieux, G. A., Liu, J., Mayer, N., Bainton, R. J., Ashrafi, K., and Werb, Z. (2011). A whole-organism screen identifies new regulators of fat storage. Nat. Chem. Biol. 7, 206-213.

Meyre, D., Delplanque, J., Chèvre, J. C., Lecoeur, C., Lobbens, S., Gallina, S., Durand, E., Vatin, V., Degraeve, F., Proença, C., Gaget, S., Körner, A., Kovacs, P., Kiess, W., Tichet, J., Marre, M., Hartikainen,A. L., Horber, F., Potoczna, N., Hercberg, S., Levy-Marchal, C., Pattou, F., Heude, B., Tauber, M., McCarthy, M. I., Blakemore, A. I., Montpetit, A., Polychronakos, C., Weill, J., Coin, L. J., Asher, J., Elliott, P., Järvelin, M. R., Visvikis-Siest,
S., Balkau, B., Sladek, R., Balding, D., Walley, A., Dina, C., and Froguel, P. (2009). Genome-wide association study for early-onset and morbid adult obesity identifies three new risk loci in European populations. Nat. Genet. 41, 157-159.

O’Rourke, E. J., Soukas, A. A., Carr, C. E., and Ruvkun, G. (2009). C. elegans major fats are stored in vesicles distinct from lysosome-related organelles. Cell Metab. 10, 430-435.

Pospisilik, J. A., Schramek, D., Schnidar, H., Cronin, S. J., Nehme, N. T., Zhang, X., Knauf, C., Cani, P. D., Aumayr, K., Todoric, J., Bayer, M., Haschemi, A., Puviindran, V., Tar, K., Orthofer, M., Neely, G. G., Dietzl, G., Manoukian, A., Funovics, M., Prager, G., Wagner, O., Ferrandon, D., Aberger, F., Hui, C. C., Esterbauer, H., and Penninger, J. M. (2010). Drosophila genome-wide obesity screen reveals hedgehog as a determinant of brown versus white adipose cell fate. Cell 140, 148-160.

Speliotes, E. K., Willer, C. J., Berndt, S. I., Monda, K. L., Thorleifsson, G., Jackson, A. U., Allen, H. L., Lindgren, C. M., Luan, J., Mägi, R., Randall, J. C., Vedantam, S., Winkler, T. W., Qi, L., Workalemahu, T., Heid, I. M., Steinthorsdottir, V., Stringham, H. M., Weedon, M. N., Wheeler, E., Wood, A. R., Ferreira, T., Weyant, R. J., Segrè, A. V., Estrada, K., Liang, L., Nemesh, J., Park, J. H., Gustafsson, S., Kilpeläinen, T. O., Yang, J., Bouatia-Naji, N., Esko, T., Feitosa, M. F., Kutalik, Z., Mangino, M., Raychaudhuri, S., Scherag, A., Smith, A. V., Welch, R., Zhao, J. H., Aben, K. K., Absher, D. M., Amin, N., Dixon, A. L., Fisher, E., Glazer, N. L., Goddard, M. E., Heard-Costa, N. L., Hoesel, V., Hottenga, J. J., Johansson, A., Johnson, T., Ketkar, S., Lamina, C., Li, S., Moffatt, M. F., Myers, R. H., Narisu, N., Perry, J. R., Peters, M. J., Preuss, M., Ripatti, S., Rivadeneira, F., Sandholt, C., Scott, L. J., Timpson, N. J., Tyrer, J. P., van Wingerden, S., Watanabe, R. M., White, C. C., Wiklund, F., Barlassina, C., Chasman, D. I., Cooper, M. N., Jansson, J. O., Lawrence, R. W., Pellikka, N., Prokopenko, I., Shi, J., Thiering, E., Alavere, H., Alibrandi, M. T., Almgren, P., Arnold, A. M., Aspelund, T., Atwood, L. D., Balkau, B., Balmforth, A. J., Bennett, A. J., Ben-Shlomo, Y., Bergman, R. N., Bergmann, S., Biebermann, H., Blakemore, A. I., Boes, T., Bonnycastle, L. L., Bornstein, S. R., Brown, M. J., Buchanan, T. A., Busonero, F., Campbell, H., Cappuccio, F. P., Cavalcanti-Proença, C., Chen, Y. D., Chen, C. M., Chines, P. S., Clarke, R., Coin, L., Connell, J., Day, I. N., den Heijer, M., Duan, J., Ebrahim, S., Elliott, P., Elosua, R., Eiriksdottir, G., Erdos, M. R. Eriksson, J. G., Facheris, M. F., Felix, S. B., FischerPosovszky, P., Folsom, A. R., Friedrich, N., Freimer, N. B., Fu, M., Gaget, S., Gejman, P. V., Geus, E. J., Gieger, C., Gjesing, A. P., Goel, A., Goyette, P., Grallert, H., Grässler, J., Greenawalt, D. M., Groves, C. J., Gudnason, V., Guiducci, C., Hartikainen, A. L., Hassanali, N., Hall, A. S., Havulinna, A. S., Hayward, C., Heath, A. C., Hengstenberg, C., Hicks, A. A., Hinney, A. Hofman, A., Homuth, G., Hui, J., Igl, W., Iribarren, C., Isomaa, B., Jacobs, K. B., Jarick, I., Jewell, E., John, U., Jørgensen, T., Jousilahti, P., Jula, A., Kaakinen, M., Kajantie, E., Kaplan, L. M., Kathiresan, S., Kettunen, J., Kinnunen, L., Knowles, J. W., Kolcic, I., König, I. R., Koskinen, S., Kovacs, P., Kuusisto, J., Kraft, P., Kvaløy, K., Laitinen, J., Lantieri, O., Lanzani, C., Launer, L. J., Lecoeur, C., Lehtimäki, T., Lettre, G., Liu, J., Lokki, M. L., Lorentzon, M., Luben, R. N., Ludwig, B., MAGIC, Manunta, P., Marek, D., Marre, M., Martin, N. G., McArdle, W. L., McCarthy, A., McKnight, B., 
Meitinger, T., Melander, O., Meyre, D., Midthjell, K., Montgomery, G. W., Morken, M. A., Morris, A. P., Mulic, R., Ngwa, J. S., Nelis, M., Neville, M. J., Nyholt, D. R., O'Donnell, C. J., O'Rahilly, S., Ong, K. K., Oostra, B., Paré, G., Parker, A. N., Perola, M., Pichler, I., Pietiläinen, K. H., Platou, C. G., Polasek, O., Pouta, A., Rafelt, S., Raitakari, O., Rayner, N.W., Ridderstråle, M., Rief, W., Ruokonen, A., Robertson, N. R., Rzehak, P., Salomaa, V., Sanders, A. R., Sandhu, M. S., Sanna, S., Saramies, J., Savolainen, M. J., Scherag, S., Schipf, S., Schreiber, S., Schunkert, H., Silander, K., Sinisalo, J., Siscovick, D. S., Smit, J. H., Soranzo, N., Sovio, U., Stephens, J., Surakka, I., Swift, A. J., Tammesoo, M. L., Tardif, J. C., Teder-Laving, M., Teslovich, T. M., Thompson, J. R., Thomson, B., Tönjes, A., Tuomi, T., van Meurs, J. B., van Ommen, G. J., Vatin, V., Viikari, J., Visvikis-Siest, S., Vitart, V., Vogel, C. I., Voight, B. F., Waite, L. L., Wallaschofski, H., Walters, G. B., Widen, E., Wiegand, S., Wild, S. H., Willemsen, G., Witte, D. R., Witteman, J.C., Xu, J., Zhang, Q., Zgaga, L., Ziegler, A., Zitting, P., Beilby, J. P., Farooqi, I. S., Hebebrand, J., Huikuri, H. V., James, A. L., Kähönen, M., Levinson, D. F., Macciardi, F., Nieminen, M. S., Ohlsson, C., Palmer, L. J., Ridker, P. M., Stumvoll, M., Beckmann, J. S., Boeing, H., Boerwinkle, E., Boomsma, D. I., Caulfield, M. J., Chanock, S. J., Collins, F. S., Cupples, L.A., Smith, G. D., Erdmann, J., Froguel, P., Grönberg,
H., Gyllensten, U., Hall, P., Hansen, T., Harris, T. B., Hattersley, A. T., Hayes, R. B., Heinrich, J., Hu, F. B., Hveem, K., Illig, T., Jarvelin, M. R., Kaprio, J., Karpe, F., Khaw, K. T., Kiemeney, L. A., Krude, H., Laakso, M., Lawlor, D. A., Metspalu, A., Munroe, P. B., Ouwehand, W. H., Pedersen, O., Penninx, B. W. Peters, A., Pramstaller, P.P., Quertermous, T., Reinehr T., Rissanen, A., Rudan, I., Samani, N. J., Schwarz, P. E., Shuldiner, A. R., Spector, T. D., Tuomilehto, J., Uda, M., Uitterlinden, A., Valle, T. T., Wabitsch, M., Waeber, G., Wareham, N. J., Watkins, H., Procardis Consortium, Wilson, J. F., Wright, A. F., Zillikens, M. C., Chatterjee, N., McCarroll, S. A., Purcell, S., Schadt, E. E., Visscher, P. M., Assimes, T. L., Borecki, I. B. Deloukas, P., Fox, C. S., Groop, L. C., Haritunians, T., Hunter, D. J., Kaplan, R. C., Mohlke, K. L., O'Connell, J. R., Peltonen, L., Schlessinger, D., Strachan, D. P., van Duijn, C. M., Wichmann, H. E., Frayling, T. M., Thorsteinsdottir, U., Abecasis, G. R., Barroso, I., Boehnke, M., Stefansson, K., North, K. E., McCarthy, M. I., Hirschhorn, J. N., Ingelsson, E., and Loos, R. J. (2010). Association analyses of 249,796 individuals reveal 18 new loci associated with body mass index. Nat. Genet. 42, 937-948.

Suh, J.M., Zeve, D., McKay, R., Seo, J., Salo, Z., Li, R., Wang, M., and Graff, J.M. (2007). Adipose is a conserved dosage-sensitive antiobesity gene. Cell Metab. 6, 195-207.
Van Veldhoven, P. P., Swinnen, J. V., Esquenet, M., and Verhoeven, G. (1997). Lipase-based quantitation of triacylglycerols in cellular lipid extracts: requirement for presence of detergent and prior separation by thinlayer chromatography. Lipids 32, 1297-1300.

Yen, K., Le, T. T., Bansal, A., Narasimhan, S. D., Cheng, J.X. and Tissenbaum, H.A. (2010). A comparative study of fat storage quantitation in nematode Caenorhabditis elegans using label and label-free methods. PLOS ONE 5, e12810. 10.1371/journal.pone.0012810

Zhang, S. O., Trimble, R., Guo, F., and Mak, H. Y. (2010). Lipid droplets as ubiquitous fat storage organelles in C. elegans. BMC Cell Biol. 11, 96. doi: 10.1186/1471-2121-11-96

Received: 19May 2011; accepted: 15 November 2011; published online: 01 December 2011.

Citation: Al-Anzi B and Zinn K (2011) Genetics of fat storage in flies and worms: what went wrong? Front. Gene. 2:87. doi: 10.3389/fgene.2011.00087

This article was submitted to Frontiers in Genomic Endocrinology, a specialty of Frontiers in Genetics.

Copyright $\odot 2011 \mathrm{Al}$-Anzi and Zinn. This is an open-access article distributed under the terms of the Creative Commons Attribution Non Commercial License, which permits noncommercial use, distribution, and reproduction in other forums, provided the original authors and source are credited. 